\title{
A területi tőke fogalmi megközelítései
}

\section{Conceptual approaches to territorial capital}

\author{
JÓNA GYÖRGY
}

KULCSSZAVAK: területi tőke, immateriális javak, versenyképesség, területi tőkejavak

ABSZTRAKT: A területi tőke koncepciója közel egy évtizede jelent meg a modern regionális tudomány terminológiai rendszerében. Ez a paradigma a helyi versenyképességet meghatározó materiális és immateriális tőkeelemeket vizsgálja. A területi tőke kategóriájának bevezetése azért fontos, mert a korábbi mérések csak a materiális javakat, a közgazdaságilag könnyen mérhető változókat elemezték. A területi tőke azonban olyan új komplex gyüjtőfogalom, mellyel a gazdasági térszerkezet mélyebb összefüggésrendszerét, vonzóképességét is lehet vizsgálni. Ebben a tanulmányban a területi tőke fogalmi elemeit, osztályozását, modelljeit, definíciós kísérleteinek eredményeit mutatom be. Megvizsgálom funkcióit, újítási lehetőségeit, legfőbb jellemzőit, módszertani eljárásának (MASST-modell) sajátosságait, valamint bemutatom az OECD és Camagni területitőke-definícióit. A területi tőke számos tőkeösszetevőt foglal magába, melyek rendszerszerűen tagolódnak, illeszkednek egymáshoz. A fogalomnak még nincs kiforrott, általánosan elfogadott definíciója, inkább definíciós kísérletekkel találkozhatunk. Ezt tovább bonyolítja, hogy a különböző fogalmi modellek más és más tőkeelemeket fogadnak el. Természetesen vannak átfedések, egyezések a modellek között, ám eltérésekkel is lehet találkozni.

KEYWORDS: territorial capital, intangible capital assets, competitiveness, taxonomy of territorial capital assets

ABSTRACT: The conception of territorial capital emerged in the terminology of modern regional sciences about ten years ago. It examines those material and intangible assets which determine local competitiveness. The introduction of the category of territorial capital is important because earlier investigations have only examined the tangible assets and the variables that can be easily measured in economic terms. However, the territorial capital is a new, complex concept through which it is possible to examine the deeper relationship system of an economic structure; it can help determine the attractiveness of a given spatial structure. In this study we introduce the terminology, the classification, the models and the results of an experiment involving territorial capital. In the first chapter we examine the functions, innovation possibilities, major characteristics and the feature of its methodical process (MASST model: MAcroeconomic, Sectoral, Social and Territorial). After this, we present the conceptual models of territorial capital as presented by the $O E C D$ and Roberto Camagni. The territorial capital includes several components which split in a systematical way and fit together accordingly. It has not found a generally accepted definition yet, so we can meet only attempts at its definition. To find a commonly accepted definition is made even more complicated by the fact that the different conceptual models use several capital elements. Of course, there are overlaps, analogies among the models but we can often find differences as well.

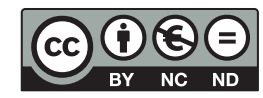




\section{Bevezetés}

A területi tőke fogalma közel egy évtizede jelent meg a modern regionális tudomány terminológiai rendszerében. Jelentése napjainkra kezd kikristályosodni, egyértelművé válni, ám fogalmi összetevői még képlékenyek, gyakran változnak; definíciói között gyakran mutatkoznak tartalmi átfedések és eltérések. Ebben a tanulmányban a területi tőke fogalmi elemeit, osztályozását, modelljeit, definíciós kísérleteinek eredményeit, jelentését, funkcióit, újdonságát, legfőbb jellemzőit, deskriptív és normatív fogalmi megközelítéseit, egymásba alakításának lehetőségeit, valamint módszertani sajátosságait mutatom be. Ezt követően az elméleti és empirikus vizsgálatokban általánosan alkalmazott, az OECD és Camagni által megalkotott területitőke-modelleket vázolom fel.

\section{A területi tőke jelentése}

Adott terület gazdasági növekedését ${ }^{1}$ nemcsak közgazdaságtani, hanem számos szociológiai, antropológiai, szociokulturális, vallási és szociálpszichológiai tényező határozza meg. A közöttük lévő viszonyrendszer fordított irányban is hat: a vallási, kulturális és társadalmi struktúrát meghatározzák a gazdasági folyamatok; ezek egymásra kölcsönösen hatnak, miközben egymást és önmagukat is formálják. ${ }^{2}$ Napjainkra egyre nyilvánvalóbb, és egyre több empirikus bizonyíték áll rendelkezésre arról, hogy a regionális gazdaság szerkezete és folyamatai sokkal pontosabban megérthetők, ha a nem gazdasági jellegű változókat (vagyis az immateriális tőkeelemeket) is beemeljünk elemzésünkbe (Rota 2010; Veneri 2011). A területi tőke fogalma alkalmas arra, hogy mindezeket a tényezőket átfogóan konceptualizálja és operacionalizálja.

A területi tőke egy olyan sokoldalú fogalom, amellyel adott térstruktúra látható és láthatatlan tőkeelemeit lehet mérni, majd segítségével a regionális neoklasszikus endogén növekedéselmélet keretei között területi fejlesztési programokat megalkotni. Újszerűsége, hogy a korábban mérhetetlennek tartott immateriális javakat tőkeként értelmezi, ugyanolyan értéket tulajdonít nekik, mint a materiális tőkének, így ezeket együttesen veszi figyelembe a területi állapotfelmérésben és a fejlesztési irányok meghatározásakor (Fabbro, Mesolella 2010). Affuso és Camagni $(2010,2$.) szerint a területi tőke fogalma segítségével számszerűsíthetők a régióban található anyagi és nem anyagi tőkeösszetevők, melyek adott terület versenyképességének erőforrásait, a regionális gazdasági fejlődés aspektusait közösen alkotják. A területi tőke a térségben található láthatatlan és fizikai tőkefajták egészén alapul, a helyben beágyazódott források elemzésére vállalkozik. Megmutatja, hogy az adott térségben milyen és mennyi látható és láthatatlan vagyonelem halmozódott fel, ezeknek milyen a területi megoszlása, illetve milyen tőketípusból mekkora a kihasználatlan kapacitás 
vagy a hiány. „A területi tőke tehát nem illeszthető be a materiális és a tárgyalt immateriális tőketípusok egyszerü folytatásaként, hanem a területi tőkében összesítendők a láthatatlan és a fizikai komponensek." (Tóth 2010, 78.)

A területi tőke olyan összetett fogalom, amellyel a gazdasági térszerkezet mélyebb összefüggésrendszerét lehet megvizsgálni, a térstruktúra tőkevonzó és tőkefelhalmozó képességét megállapítani (ESPON 2011, 80-81.), és amely szorosan követi a területitőke-állomány pontszerü vagy halmazos jellemzőit (Rechnitzer 2010, 1.). Az immateriális javak meghatározó elemei a lokális közösség, a térgazdasági feltételek és folyamatok, a földrajzi tényezők, a területi miliő, a habitus és a beágyazottság, valamint az identitás és a kultúra (Czarnitzki, Hottenrott 2009). A területi tőke funkciókra és viszonyokra vonatkozó kategóriája differenciáltan jeleníti meg egy terület legfőbb jellemzőit (Illés 2009, 217.), továbbá holisztikusan, integrált szemléletben, dinamikájában képes a regionális folyamatokat magyarázni (Tóth 2011, 141.). Keresztmetszeti és longitudinális felmérések elkészítésére alkalmas paradigma, amely interdiszciplináris szemléletű, és leginkább a szociológia, a politika- és a közgazdaság-tudomány elméleti megközelítéseit és módszertani eljárásait szintetizálja (Zamora, Jou, Williams 2008). A megközelítés az alulról induló kezdeményezéseket, a decentralizált, lokális beavatkozást, a politikai-közösségi irányítást, a területi autonómia megőrzésével a többszintủ kormányzást és a kínálatorientált területfejlesztési programokat preferálja. Vagyis a helyi önkormányzatiság és a szubszidiaritás elve organikusan összefonódik a területi tőke gondolatkörével (Ágh 2007).

A területi tőke elképzelése az elmaradott térségek felzárkóztatásához újszerű módon képes segítséget nyújtani, mert a térség azon látható és láthatatlan forrásait is figyelembe veszi, amelyek korábban esetleg nem, vagy csak részben jelentek meg a területi elemzésekben. Jó példát hozott erre Kunzmann (2009), megkülönböztetve a középvárosok sajátos területi növekedésének lehetséges forrásait, úgymint regionális identitás, lokális hallgatólagos tudás és lokális képességek, építészeti örökségek, nyelvhasználat és nyelvtudás, lokális üzleti szereplők társadalmi és gazdasági beágyazottsága, közösségi formális és informális hálózatok, helyi média, regionális civil társadalom, helyi kulturális és gazdasági hagyományok. „A kínálatorientált szemléletű területi tőke gondolatköre kiválóan összegzi és rendszerezi az összes olyan tényezőt, amelyek az endogén fejlődés vizsgálatánál illetve az alulról szerveződő fejlesztési elképzelések kidolgozásánál fontosak lehetnek. Ez a gondolatkör elismeri, hogy létezik területi verseny, nem automatikus a fejlődés, emiatt a haladáshoz tevékenyen tennie kell a helyi közösségnek is, egyféle »versenystratégiát « kidolgozva a területi tőke megerősítésére." (Lengyel 2012,163.)

A területi tőke koncepciójának kidolgozásával a régió versenyképességének javítása és a lokális társadalom jólétének növelése a cél (Faludi 2006, 672.). Fontos kiemelni, hogy a területi tőke figyelembe veszi a lokális jólét azon sajátos vonását, hogy a gazdasági fejlődés - az egyre inkább beszükülő, valamint romló forrásallokációs hatékonyságú újraelosztási csatornák miatt - nem min- 
dig járul hozzá közvetlenül a társadalmi jólét eléréséhez (Barca 2009; OECD 2001, 16.). Ez annak is köszönhetö, hogy a profitnövekedés számos esetben csak a tulajdonosi oldalon realizálódik, nem jut el az újraelosztásért felelős intézményrendszerig, vagyis végső soron nem jelenik meg a lakossági jövedelmekben, nem „csorog le” a fogyasztókhoz és a helyi termelőkhöz. A területi tőke koncepciója alkalmas arra, hogy a forráselosztási mechanizmusok működési hibáját összekapcsolja a társadalom jólétének szintjével, azaz a társadalom állapotát, szerkezetét és egyenlőtlenségeit plasztikusan veti össze a gazdasági struktúrával.

A területi tőke paradigmájában egymással komplementer viszonyban áll a deskriptív és a normatív személetmód (Jóna, Tóth 2012). Előbbi pozitivista nézőpont empirikus adatfelvétellel összegyüjti és tárgyiasítja a térstruktúrában fellelhető immateriális tőketípusokat, azokat leíró módon, felsorolásszerűen mutatja be. E megközelítés egyedüli szerepe, hogy a területi viszonyrendszerekről és állapotokról diagnózist készítsen. Ilyen kutatási eredményekről számol be Camagni, Caragliu, Perucca 2011, Capello, Caragliu, Nijkamp 2009 és Rota 2010. A normatív szemlélet ezen túlmenően a területi helyzetfelmérést követően problémamegoldó modelleket, alternatívákat, területi terveket dolgoz ki a feltárt működési zavarok kezelésére és a térbeli differenciálódás mérséklésére, megállapítja a település- és területfejlesztési koncepciók háttérfeltételeit, kijelöli a beavatkozás irányait (Veneri 2011; Giffinger, Suitner 2010; Russo, Smith, Atkinson, Servillo, Madsen, Borg, Otgaar 2012). A szubszidiaritás elve központi szerepet tölt be a normatív megközelítésben, mert elősegíti mindazon kritériumrendszerek gyakorlati alkalmazását, amelyek megőrzik, fenntartják és újratermelik az agglomerációs, urbanizációs és klaszterelőnyöket, valamint a külső és belső méretgazdaságosságból eredő hasznot. A területi tőke mérésével tehát egy adott térség fejlettségi szintjének megállapításához (helyzetfelmérés) és a gazdasági növekedés fenntarthatóságához járulhatunk hozzá. Mindez szükségessé teszi a területi tőke koncepciójának alkalmazását a regionális tudományban (Marsden, Ploeg 2008, 233.).

\section{Az immateriális javak szerepe a területi tőke koncepciójában}

Napjainkra bizonyítottá vált, hogy egy térség gazdasági értékét nemcsak a látható, hanem az immateriális tőke is befolyásolja. „A regionális GDP nem lehet a különbségek egyetlen mércéje, mert a régiók GDP-je közelíthet egymáshoz, miközben az emberek és a társadalmak helyzetében való különbségek növekednek. (...) Fabrizio Barca 2009 áprilisában készített jelentése - Barca-jelentés - azt állítja, hogy a fejlődést és a hatékonyságot az szolgálja leginkább, ha minden régió adottságait, lehetőségeit, potenciálját, területi tőkéjét a lehető legnagyobb mértékben használjuk fel, és aknázzuk ki. (...) A területi tőke alapú megközelítésekkel rámutathatunk arra, hogy a regionális GDP-ben mért régiók hátránya vagy előnye mégsem pontosan annyi, mint ahogy azt a regionális GDP 
mutatja." (Tóth 2010, 79.) Emellett érvelt a szociológus Bourdieu is (akinek gondolataiból a regionális tudomány sokat merített), aki szerint: „a társadalmi világ struktúráját és működését akkor ítélhetjük meg csak helyesen, ha a tőke fogalmát nem csupán a közgazdaságtanból ismert formában, hanem valamennyi megjelenési formájában vezetjük be." (Bourdieu 2004, 123.).

Az immateriális erőforrások területi vonatkozására elsőként Marshall - a cambridge-i közgazdaságtani iskola egyik alapítója - hívta fel a figyelmet, később pedig a World Bank (2006) egyik tanulmánya hangsúlyozta ezen tőkeelemek régiókra gyakorolt hatását. Marshall ezeket az erőforrásokat nem láthatatlan, hanem „levegőben lévő” (in the air) javaknak nevezte, amelyek szerinte a gazdasági környezet jellemvonásait adják. Meghatározó tényezői közé sorolta a térségben lévő intézményi hálózatot, a formális és informális szabályokat, a helyi kutatók, politikusok és termelők normáit és érdekérvényesítő képességeit, valamint a lokális gazdaságban bevett szokásokat és gyakorlatokat.

A gazdasági mutatószámok javulása csupán egyike a regionális növekedés kritériumainak, mert a GDP alakulásával nem lehet megfelelő formában kifejezni a térbeli folyamatok fejlődési irányait. A területi gazdasági fejlődést ma már nemcsak közgazdasági, hanem szociológiai jellegü folyamatok is meghatározzák. A területi tőke fogalma ennek megfelelően a gazdasági fogalmak mellett figyelembe veszi a szintén nagy gazdasági befolyással bíró immateriális tőkeösszetevőket, amelyeket további társadalomtudományi (szociológiai, szociálpszichológiai stb.) módszerekkel és megközelítésekkel értelmez (Servillo 2010). Az immateriális tőkeelemek feltárása és újratermelési feltételeinek megteremtése egyre fontosabbá válik, mert a fizikai tőke korlátozottan áll rendelkezésre (Zonneveld, Waterhout 2005). Feltételezhető, hogy ezek a láthatatlan javak a jövőben bizonyos mértékig fokozatosan kiváltják, pótolják vagy akár le is cserélik a materiális javakat (Tóth 2010, 77-78). Az immateriális tőkeelemek egyre nagyobb szerepet kapnak a helyi gazdaságszerkezetben, mert a klasszikus termelési tényezők (az anyagi kapacitások) korlátozottan állnak rendelkezésre. A véges természeti erőforrások kiváltására részben vagy egészben alkalmasak az immateriális tőkekomponensek, így biztosítva a gazdaság önreprodukciós képességét és fenntarthatóságát.

A nem tárgyi tőkejavakat is tőkeként kell felfogni, mert ugyanolyan értéket képviselnek, mint a tárgyiasult források (Luukkonen 2010, 46.). A területi tőke fogalmában a tőke szó utal arra, hogy a láthatatlan tőkeformák a látható vagyonelemekhez hasonlóan felhalmozhatók, mobilizálhatók, elveszíthetők és amortizálhatók (Faludi 2006).

Az immateriális tőkefajták egyaránt kötődhetnek az egyénhez, a közösséghez és a térstruktúrához. Legnagyobb részüknek mobilitása nem olyan gyors, mint a tárgyiasult tőkéé, mert - vegyük észre - a megfoghatatlan javak rendszerint társadalmilag meghatározottak, szorosan kapcsolódnak a társadalom egyes tagjaihoz vagy valamilyen közösséghez. Az egyénhez füződő nem tárgyi jószágokat a belföldi és a nemzetközi migráció tényezői befolyásolják. A szociológia megállapításai jelentősek ebben a vonatkozásban is: „A társadalmi tőke 
fogalmával és lényegi jellemzőivel kapcsolatban egyes szociológiai irányzatok alapvető eredményeket értek el, a regionális tudományban is megjelent a területi tőke fogalma." (Lengyel 2010, 285).

Az immateriális források egy kisebb halmaza a térszerkezethez kapcsolódik, földrajzilag meghatározott, mozdíthatatlan, illetve esetenként magát a teret jelenti, mely önmagában is nem anyagi értéket képvisel. A földrajzi helyzet nem mobil adottság, ezért ha a mozdíthatatlan tér valamilyen megfoghatatlan értéket képvisel, akkor az lokalizációs előnyt, kiszámítható értéket képviselhet a térség számára a gazdasági egységek között (Brenner 2004). Brenner továbbá kiemeli, hogy a fizikai tőke közvetlenül és gyorsan reagál a gazdasági tendenciák változására (legyen az kedvező vagy hátrányos), a nem tárgyi javak értéke viszont nem, vagy csak később módosul a gazdasági változás hatására.

A területi tőke számba veszi mindazokat a forrásokat, melyek gazdasági előnyöket jelentenek, illetve jelenthetnek a térségben. Egyaránt méri azokat az anyagi és nem anyagi lehetőségeket, melyek már hozzájárultak a lokális jóléthez, és azokat is, melyek egyelőre kiaknázatlan források (Russo, Servillo 2011). A területi tőke tehát magába foglalja a versenyképesség összes elemét, ám annál tágabb és összetettebb fogalom (Faludi 2010, 11.). Giffinger (2007) egyik elemzésében talán elsőként próbálja meg összehasonlítani a területi tőke paradigmáját és a regionális versenyképesség fogalmát. Hangsúlyozza, hogy a két modell célja azonos: az adott régió jólétének megteremtése és fenntartása. A két megközelítés közötti legszembetűnőbb eltérés az, hogy a területi tőke a nem anyagi javakat a területi verseny fontos forrásaként értelmezve operacionalizálja. Továbbá szembetűnően nagyobb szerepet tulajdonít az endogén fejlesztési lehetőségek közül a tudás/képesség funkcionális térbeli helyzettel kombinált tényezőjének (Capello 2008). A funkcionális térbeli helyzetet a térség természeti adottságai, a materiális és immateriális örökségek, a termelési eszközökkel kapcsolatos örökségek és a helyi társadalom kompetenciái adják.

A helyi társadalom tagjai és szervezetei gyakran evidenciaként tekintenek területi adottságaikra, nem veszik észre a bennük rejlő lehetőségeket, megfogható forrásként tekintenek rájuk. Az immateriális lehetőségeket tehát elsőként fel kell ismerni, utána lehet őket mobilizálni.

A megfoghatatlan tőkekomponenseket materiális javakká kell átalakítani az életszínvonal javítása és a lokális jólét megteremtése érdekében. A nem anyagi tőkejavak az átalakítás révén anyagi tőkévé formálhatók, ahogy azt korábban Camagni és Fratesi $(2011,18$.$) egyértelműen levezették. Az átalakítás$ többszörös áttételü, ismétlődő folyamatának feltétele a szimbolikus tőke birtoklása, amelyet Bourdieu (1983) ír le. A szimbolikus tőke egyéni vagy intézményi adottság, olyan képesség, mely alkalmassá teszi az egyént vagy a szervezetet arra, hogy a már rendelkezésére álló tőkefajtát egy másik tőkefajtává alakítsa (például kulturális tőkéből gazdasági tőkét, majd kapcsolati tőkét hozzon létre, amelyből újabb gazdasági előnyt szerezhet). Egy adott tőketípus megléte még egyáltalán nem garancia arra, hogy abból majd egy másik tőkefaj- 
ta felhalmozhatóvá válik, ennek megvalósításához szimbolikus tőkére van szükség. Területi szempontból a szimbolikus tőke olyan különleges képességet jelent, mellyel egy térség immateriális tőkeformáit fizikai tőkejavakká tudja formálni, vagy viszont. Nem evidens ugyanakkor, hogy a magas gazdasági tőkével rendelkező egyén magas kulturális tőkével is bír, valamint a magas kulturális tőkével rendelkezőnek sincs mindig birtokában magas gazdasági tőke - ez a szimbolikus tőke hiányával, illetve kihasználatlanságával magyarázható. Az immateriális tőkeformák tárgyiasult tőketípussá változtatásához tehát egy térség vezetőinek és a társadalom tagjainak szimbolikus tőkéjére van szükség, amit megfelelő keretek között kell érvényesíteniük.

A területi tőke felhalmozásának feltételrendszere kapcsolatban áll a szimbolikus tőke szerepével (Damsgaard 2009). A területi tőke felhalmozása és a láthatatlan tőkeelemek fizikai tőkévé történő átalakítása csak akkor valósítható meg, ha az intézményes, kognitív és mentális konstrikciós (hátráltató, gátló) hatások minimalizálódnak (esetleg eltűnnek, bár a valóságban ilyen ritkán fordul elő), ezen túlmenően pedig a közösség tagjainak az intézményi, szervezeti, társadalmi és mentális közelség feltételeit is meg kell teremteniük. Damsgaard a területi tőke és a társadalmi integráció összefüggésrendszerében értelmezi a regionális növekedési potenciált.

A területi tőke nagysága és a gazdasági növekedés között pozitív korreláció mutatható ki. Minél nagyobb az adott régió területitőke-ellátottsága, annál magasabb a fejlettségi szintje. Ez a megállapítás természetesen néhány szigorítás mellett állja meg a helyét: a területi tőke nem anyagi része önmagában csak ritkán jelent valódi értéket, ezt fel kell ismerni, aktualizálni, mobilizálni szükséges. Az immateriális javak a regionális gazdasági fejlődéshez akkor tudnak hozzájárulni, ha a helyi társadalom tagjai felismerik, használják és a szimbolikus tőke révén anyagi tőkévé alakítják ezeket.

A területi tőke paradigmájából származó kutatási eredményeket fel lehet használni a terület- és településfejlesztésben, a területi tervezésben, valamint piaci befektetések területi tervezésében. Alkalmazása így nem öncélú és nem csak elméleti alapon történik, hanem a gyakorlatban is pénzügyi elönyökkel kecsegtet. Figyelembe veszi az üzleti szféra szereplőinek érdekeit, mert megmutatja, hogy adott területen mely tőkeelem halmozódott fel, hol van tőkehiány, hol gyorsabb a befektetett tőke megtérülése, mely térségekben használhatók ki jobban a területi potenciálok. Ebben az összefüggésben az elképzelés szerepe az, hogy feltérképezze a tér azon látható és láthatatlan tőkekomponenseit, melyek felhasználásával a fizetőképes kereslet igényeivel szinkronban lévő áruk termelhetők. „A területi tőke bizonyos beruházásoknál nagyobb hozamot tesz lehetővé, mint másoknál, mivel azok jobban illeszkednek a területhez, és annak eszközeit, embereit és potenciálját hatékonyabban használják fel." (OECD 2001, 16) 


\section{A területi tőke fogalmi modelljei}

A területi tőke számos, egymáshoz illeszkedő összetevőt foglal magába. A fogalomnak még nincs kiforrott, általánosan elfogadott definíciója, inkább definíciós kísérletekkel találkozhatunk, a különböző fogalmi megközelítések egymástól eltéro tőkeelemeket tartalmaznak. „Az újtőke kategóriák, tartalmak azonban napjainkig még nem tisztázottak." (Tóth 2010, 67.) Természetesen az elképzelések között vannak átfedések és egyezések, ám jelentős különbségekkel is lehet találkozni. A területi tőke meghatározó tényezőit több modell is megpróbálta tipizálni és rendszerbe foglalni. Ebben a fejezetben ezeket a fogalmi rendszereket mutatom be.

\section{Az OECD modellje és későbbi definíciók}

Elsőként az OECD (2001) Territorial Outlook című jelentésében definiálták és alkalmazták a területi tőke fogalmát (1. táblázat). Ez a kísérleti meghatározás időtállónak bizonyult, logikája és tartalma szinte mindegyik későbbi szisztémában fellelhetö.

A modell a területi tőke három forrását különíti el: a látható tényezőket, a láthatatlan összefüggéseket és a megfoghatatlan tényezőket. E három kategória egymástól csupán elméleti szinten választható külön, a valóságban kölcsönösen meghatározza egymást. A három rész (a természeti és területi tényezők, valamint a térség gazdasági szereplöihez és a lokális társadalom tagjaihoz együttesen hozzárendelhető anyagi és nem anyagi tőkeelemek) összege adja a területi tőke összértékét. Az OECD mindvégig hangsúlyozza a területi tőke koncepciójában az endogén fejlődés társadalmi, kulturális (történelmi) háttérfeltételeit

1. táblázat. A területi tőke forrásai az OECD szerint

Sources of territorial capital (according to the OECD)

\begin{tabular}{lcl}
\hline \multicolumn{1}{c}{ Látható (fizikai) tényezők } & Láthatatlan összefüggések & $\begin{array}{c}\text { Megfoghatatlan (immateriális) } \\
\text { tényezók }\end{array}$ \\
\hline - Földrajzi fekvés & - Hallgatólagos megállapodások - Intézmények \\
- Terület nagysága & - Szokások és informális szabá- - Szabályok \\
- Termelési tényezőkkel való & lyok, melyek bizonytalan fel- & - Szokások \\
ellátottság & tételek között is lehetővé te- & - Maguk a termelők \\
- Klíma & szik a gazdaság szereplői szá- & - Kutatók \\
- Tradíciók & mára az együttműködést & - Helyi politikusok \\
- Természeti erőforrások & - Szolidaritás & - Utóbbi két csoport valamilyen \\
- Életminőség & - Kölcsönös segítségnyújtás & kombinációja, amely bizonyos \\
- Méretgazdaságossági előnyök & - Az új gondolatok elfogadása & kreativitást és újítást tesz le- \\
& kisebb közösségekben & hetővé \\
\hline
\end{tabular}

Forrás: saját szerkesztés OECD 2001, 15. alapján. 
(OECD 2001, 15-16.), melyek közösen járulnak hozzá a regionális versenyképesség javulásához és a regionális fejlődéshez (Kunzmann 2011, 604., Stein 2010).

A fizikai tényezők rendszerint relatív előnyöket, a láthatatlan összefüggések és az immateriális tényezők általában abszolút előnyöket foglalnak magukba (Giffinger 2007, 10.). Ezt a felfogást vallja a Zonneveld és Waterhout (2005) szerzőpáros is, amikor a területi tőke paradigmájának elsősorban regionális szintű alkalmazása mellett érvelnek. Tanulmányukban elkülönítették egymástól a térség strukturális jellemzőit és a földrajzi-térségi helyzettel összefüggő sajátosságokat. Későbbi tanulmányukban (Zonneveld, Waterhout 2010) a területi tőke koncepciójának kettősségét megőrzik, azzal a változtatással, hogy a strukturális jellemzőket kemény (hard) változóknak nevezik (ide sorolják a földrajzi tényezőket, infrastruktúrát, természeti erőforrásokat stb.), a puha (soft) változók közé sorolják a társadalmi-kulturális jegyeket (intézmények, bizalom, helyi kormányzati struktúra stb.).

Dematteis és Governa (2005) a területi tőke négy csoportját különítik el. A földrajzi helyzet, a regionális adottság nézőpontjából határozzák meg a területi tőke jelentését; nem tesznek lényegi különbséget a materiális és immateriális tőkejavak között. Ennek alapján a területi tőke csoportjait a következők alkotják:

1. az örökölt természeti és gazdasági javak, melyek létrehozásához sok időre van szükség (pl. turizmus alapját képező cseppkőbarlang, természeti látványosság, gyógyvíz stb.),

2. a térségben található általános kollektív javak, melyek nem megoszthatók, magántulajdonba nem, vagy korlátozottan kerülnek,

3. a térség egyediségét alkotó mozdíthatatlan, állandónak tekinthető attrakciók,

4. a tér egy bizonyos minőségben kizárólag az adott területen megtalálható jellegzetességei.

A szerzők szerint a területi adottságokat (mint potenciális forrásokat) azok kihasználásával és müvelésével lehet gazdasági tőkévé átalakítani. A helyi adottságok felfedezésével és mobilizálásával rendszerint a turizmus valamely szereplője fejleszthető (Dansero, Puttilli 2010, 326.).

Az Európai Bizottság (European Commission 2005, 3.) szakértői dokumentumában nem tesz különbséget a területi tőke meghatározó tényezői között, csupán taxatív módon felsorolja őket. Ezek között megtalálható az agglomerációs előny, a policentrikus városstruktúra, a megközelíthetőség, a képzett munkaerő, a kkv-k és magas iskolai végzettségűek egymáshoz viszonyított aránya az adott régióban, az üzleti hálózatok száma és müködése, a társadalmi tőke, a természeti források és kulturális örökségek termékei és a területi identitás. A dokumentum kiemeli, hogy a helyi társadalom fennmaradása és újratermelése érdekében tagjainak ezeket a forrásokat védeni és folyamatosan újraértelmezni szükséges.

Dansero és Mela (2007) szerint (az előzó állásponthoz hasonlóan) a területi tőke csoportosításának alapját a térség földrajzi adottságai adják. Az anyagi jó- 
szágokat passzív területi örökségnek nevezik, melyek közvetett módon határozzák meg a regionális fejlődést; a nem anyagi javakat aktív, dinamikus területi forrásként fogják fel, mely általában közvetett, néha közvetlen hatással van a növekedésre.

Ventura, Milone és van der Ploeg (2010) a területi tőke meghatározásánál a szimbolikus tőke szerepét helyezik a középpontba. Alapvetően hat tőkefajtát különböztetnek meg egymástól, melyek között a szimbolikus tőke a felhalmozáson túl közvetítő szerepet is kap. A (1) környezeti tőkéhez a kőolaj, a víz, a növényés állatvilág és egyéb, nem mesterségesen előállított környezeti elemek tartoznak. A gazdasági tőke (2) a térség gazdasági szerkezetével áll kapcsolatban, gazdasági folyamatok, szolgáltatások és hálózati rendszerek alkotják. A humán tőke (3) a lexikális tudáson túlmenően magába foglalja a helyi társadalom képességeit, kompetenciáit, gyakorlatait is, amelyek együttesen a térség termelési háttérfeltételeit biztosítják. A kulturális tőkéhez (4) sorolják a történelmi és művészeti örökségeket. Az intézményi tőke (5) a régió életfeltételeinek egészét integrálja: a helyi intézmények szerepe helyi szinten erős, a formális érdekérvényesítés és a konszenzuskeresés ezen a szinten egyre fontosabbá válik (Győrffy 2012). A szimbolikus tőkének (6) kiemelt funkciót tulajdonítanak Bourdieu alapján. Hangsúlyozzák, hogy egyetlen tőkefajta birtoklása révén csak korlátozott profit realizálható, a tőkeelemek kihasználása csak egyik tőkekomponens más tőkefajtára való, a szimbolikus tőke általi átalakításával valósulhat meg.

\section{Camagni definíciós modellje}

Camagni $(2008,2009)$ modellje a területi tőke nem kettő (materiális és immateriális), hanem három összetevőjét (tárgyi, vegyes és nem tárgyi javak) határozza meg, ${ }^{3}$ ezáltal a területi tőke árnyaltabb, diverzifikáltabb jelentését adja. Fontos, hogy ezek az összetevők nem hierarchikus viszonyban, hanem egymás mellé rendelt, komplementer kapcsolatban állnak egymással. A modellben (1. ábra) Camagni a területi tőke kilenc elemét definiálja, ami alapján elkülöníthetők egymástól az abszolút és a relatív versenyképességet meghatározó látható és láthatatlan tőkejószágok (Giffinger, Haindlmaier, Kramar 2010, 309.; Giffinger, Gudrun 2010, 25.). Úgy véli, hogy ez a kilenc tőkefajta befolyásolja leginkább a helyi potenciálok kiaknázását.

A modell nemcsak elméleti, hanem empirikus kutatások keretrendszerét is adja - az első területitőke-vizsgálatok rendszerint ezen elképzelések szerint készültek. A megoldás előnye az, hogy városi, középvárosi, regionális (statisztikai, homogén és csomóponti régiók egyaránt), metropolisz-, fővárosi, nemzeti és nemzetközi szinten is alkalmas a területi tőke eloszlásának és felhalmozásának empirikus vizsgálatára (Giffinger, Suitner 2010,14.).

A területi tőke rendszertanában kiemelt jelentősége van a pénzügyi forrásoknak, a müszaki infrastruktúrának, a humán erőforrásoknak, a helyben található és állandóan fejleszthető piacképes tudásnak, a kapcsolati hálónak, valamint 
1. ábra. A területi tőke elméleti osztályozása Theoretical classification of territorial capital

\begin{tabular}{|c|c|c|c|}
\hline $\begin{array}{l}\text { (magán- } \\
\text { javak) }\end{array}$ & \begin{tabular}{l} 
C. Privát állandó tőke és \\
tókehasználatidí-köteles \\
\multicolumn{1}{c}{ javak } \\
Magánállótőke-állomány \\
Pénzbeli externáliák \\
(hard) \\
Díjköteles javak (kizáróla- \\
gosság)
\end{tabular} & $\begin{array}{l}\text { I. Kapcsolati magánszolgálta- } \\
\text { tások } \\
\text { - A cégek külső kapcsola- } \\
\text { tai } \\
\text { - K+F-eredmények } \\
\text { transzfere } \\
\text { Egyetemi spinoffok }\end{array}$ & $\begin{array}{l}\text { F. Humán tóke } \\
\text { - vállalkozókészség } \\
\text { - kreativitás } \\
\text { - magán know-how } \\
\text { Pénzbeli externáliák (soft) }\end{array}$ \\
\hline $\begin{array}{c}\text { (klubjavak) } \\
\text { (kevert } \\
\text { közjavak) }\end{array}$ & $\begin{array}{l}\text { B. Köztes, vegyes rivalizáló } \\
\quad \text { javak } \\
\text { Tulajdonosi hálózatok } \\
\text { Kollektív javak: } \\
\text { - tájkép } \\
\text { - kulturális örökség }\end{array}$ & $\begin{array}{l}\text { H. Kooperációs hálózatok } \\
\text { - stratégiai szövetség a } \\
\text { K+F-ben és a tudásban } \\
\text { - PPP a szolgáltatásokban } \\
\text { és a tervezésben } \\
\text { Természeti és kulturális } \\
\text { erőforrások kormányzása }\end{array}$ & $\begin{array}{l}\text { E. Kapcsolati tóke } \\
\text { - együttműködési képes- } \\
\text { ség és kollektív tevé- } \\
\text { kenység } \\
\text { - } \text { kollektív kompetenciák }\end{array}$ \\
\hline (közjavak) & $\begin{array}{l}\text { A. Közjavak és források } \\
\text { Források: } \\
\text { - természeti } \\
\text { - kulturális } \\
\text { Társadalmi állótőke: } \\
\text { - infrastruktúra }\end{array}$ & $\begin{array}{l}\text { G. Ügynökségek a K+F transz- } \\
\text { ferére } \\
\text { Az új eszközök befogadása } \\
\text { Agglomerációs és urbani- } \\
\text { zációs előnyök }\end{array}$ & $\begin{array}{l}\text { D. Társadalmi tőke } \\
\text { (önkéntes részvétel) } \\
\text { - intézmények } \\
\text { - magatartásminták, } \\
\text { modellek, értékek } \\
\text { - bizalom, reputáció }\end{array}$ \\
\hline Alacsony & $\begin{array}{l}\text { Tárgyi javak } \\
\text { (hard) }\end{array}$ & $\begin{array}{l}\text { Vegyes javak } \\
\text { (hard + soft) }\end{array}$ & $\begin{array}{c}\text { Nem tárgyi javak } \\
\text { (soft) }\end{array}$ \\
\hline
\end{tabular}

Forrás: Camagni 2009, 123.

az egyben a térségi identitást is meghatározó tárgyi és történelmi örökségnek.

A modell négy sarkában (A, C, D, F) azok az elemek találhatók, melyek a regionális növekedés klasszikus forrásainak tekinthetők. A középső keresztet alkotó egységek (a szürke színnel jelölt elemek) komplex innovációs teljesítményekért felelősek, vagyis a tudásteremtésben és a tudás felhalmozásában játszanak fontos szerepet; Camagni szerint pozitív externáliákként is értelmezhetők (Camagni 2009, 7.).

Most nézzük meg, hogy Camagni miként értelmezi a kilenc komponenst!

\section{A. Közjavak és források}

Ebbe a kategóriába Camagni szerint a térségben található anyagi tőkék és az infrastruktúra sorolható. Az összetevő a térség gazdasági vonzerejének egyik alapja, de kihasználását torzíthatja a földhasználati díj emelése, az amortizáció és a termőföld környezetszennyező használata. Ezeket decentralizált szabályozással korrigálni lehet, a kárt esetleg büntetések kiszabásából befolyt forrásokkal lehet helyreállítani. 


\section{B. Köztes, vegyes rivalizáló javak}

Ebben a csoportban a magán- és köztulajdonban lévő tőkeformájú műszaki berendezések, kommunikációs rendszerek, úthálózat és kulturális örökségek találhatók. Ha a lokális térben a kulturális örökség szerepe erős, akkor a helyi identitás és kötődés is fontossá válik, a gazdasági és társadalmi interakciók javulnak, a gazdasági növekedést ösztönző területi miliő alakul ki.

\section{Privát állandó tőke és tökehasználatidíj-köteles javak}

Hagyományosan ide tartozó elem a privát állandó tőke. Hosszú távon olyan regionális környezet megteremtése a cél, hogy ez a tőkefajta a régióban maradjon, esetleg halmozódjon. Ehhez számos jogi, társadalmi és gazdasági feltételrendszernek kell rendelkezésre állnia. A privát tőke akkor nem vándorol el, ha a térségben fellelhető fizetőképes kereslethez illeszkedő terméket állít elő. A tőkehasználatidíj-köteles javak közé azok tartoznak, melyek a közösségi tulajdon részét képezik, és igénybevételi vagy használati díjat vetnek ki rájuk azért, hogy ebből fedezzék működtetésük révén történő amortizációjukat, valamint fenntartási és működési költségüket.

\section{Társadalmi tőke}

A regionális tudományban a társadalmi tőke fogalmát szinte már tradicionálisan Bourdieu (2004), Putnam (2000) és Coleman (1988) munkái alapján definiáljuk. A társadalmi tőke csupán a mozgósítható humán kapcsolatokat mutatja, a kreatív tőke a társadalmi tőke egyik létrehozója. A többi fogalmi megközelítéssel megegyezően Camagni is az immateriális javak közé sorolja a társadalmi tőkét, amely létrejöhet közösségek vagy vállalatok között, mindkét esetben gazdasági hasznot hozva. A társadalmi tőke a régió - vagy akár az interregionális gazdasági, intézményi és társadalmi viszonyrendszer - kohéziós ereje, szervező elve. Magába foglalja a társadalom írott és íratlan normáit, melyek az interakciók intenzitására és minőségére komoly hatást gyakorolnak. A piaci eredményességnek nagy lendületet adhat a társadalmi tőke, hiszen a formális és informális kommunikációs csatornák alkalmazása nélkülözhetetlen az innovációs potenciál javulásához. Camagni szerint a társadalmi tőke a térgazdasági folyamatokra gyakorolt közgazdaságtani hatása alapján számszerűsíthető, elsősorban a gazdasági és társadalmi kapcsolatokban megjelenő bizalomban manifesztálódik. Ha ez a bizalom kialakul az érintett szereplők között, akkor az az adott régiót a többi vállalkozás számára vonzóbbá tevő, a foglalkoztatást és a kibocsátást növelő gazdasági miliőt teremt.

A regionális tudományban a társadalmi tőke a gazdasági fejlődés egyik feltételeként értelmezett társadalmi integrációt jelenti. Bourdieu (2004) szerint a társadalmi integráció az egyén közösséghez való tartozását, társadalomba való beilleszkedésének sikerét méri; a csoporthoz való tartozás már önmagában profitot hoz létre. „A társadalmi tőke azon aktuális és potenciális erőforrások összessége, amelyek a kölcsönös ismertségek vagy elismerés többé-kevésbé in- 
tézményesült viszonyai tartós hálózatának birtoklásához kapcsolódnak, vagy másként kifejezve, olyan erőforrásokról van szó, amelyek az egy csoporthoz való tartozáson alapulnak.” (Bourdieu 2004, 130.) A társadalmi tőke azokat a társadalmi kapcsolat- és viszonyrendszereket fogja át, melyek bármikor mobilizálhatók az egyén gazdasági, pszichés, szociális céljai érdekében. A társadalmi tőkét meghatározza, hogy a mozgósítható személyek mennyi és milyen tőkefajtát gyüjtöttek már össze. Ide kapcsolódik továbbá, hogy az egyén általában olyan személyekkel alakít ki kapcsolatot, akik hozzá hasonló társadalmi státuszban vannak. Vagyis a több tőkeelemmel rendelkezők hamarabb tudnak problémáik kezelésében olyan egyéneket mozgósítani, akik szintén sokfajta tőkét halmoztak már fel - és ez fordítva is igaz, ami összességében regionális egyenlőtlenségeket hoz létre és termel újra. A társadalmi tőke nem magától alakul ki, mesterségesen kell létrehozni és fenntartani ahhoz, hogy hasznot hozzon.

A bizalom mint gazdasági faktor nem csak a regionális gazdaságtanban bukkan fel egyre többször, hanem a makrogazdasági elemzésekben is. A két megközelítés között az eltérés csupán annyi, hogy a regionális gazdaságtanban a bizalmat mint láthatatlan tőkejószágot társadalmi tőkének nevezzük. A továbbiakban a makrogazdasági eredményeket helyezem el a regionális gazdaságtanban.

A bizalom nem csak a hétköznapi életet, hanem a gazdasági folyamatokat is meghatározza (Hodosi 2011). A bizalom szerepe a közgazdaságtanban akkor jelenik meg, ha a gazdasági szervezetek vagy üzletfelek között bizalmi viszony jön létre, ezáltal csökkennek az adminisztrációs költségek (azon információk összegyűjtéséből származó kiadások, melyeket akkor is összegyüjtenének, ha erre nem kötelezné jogszabály a feleket) és a tranzakciós költségek (azon információk összegyüjtéséből származó kiadások, melyeket a felek jogszabályi kötelezettségből gyűjtenek össze). A bizalom lehetővé teszi, hogy ne legyen szükség jogi és etikai normákat kikényszerítő intézményekre. A bizalom könnyebben létrejön a térbeli, társadalmi és kulturális közelségben élők között. A bizalom olyan kooperációs magatartásminta, mely során az emberek közötti viszonyban mérséklődik vagy akár eltűnik a gyanakvás. Az egyéni vagy gazdasági mikroszervezetek közötti bizalomnak árcsökkentő szerepe van. Ennek egyik igazán szembetűnő és ritka példája volt az újkori gyémántkereskedelem, amelyben a zsidó kereskedők nem írtak alá szerződéseket, nem vezettek magas kiadásokkal járó formális adminisztrációt, hanem egy kézfogással elintézettnek, véglegesnek vették a cserét; így a bizalmi viszony minimalizálta az üzleti folyamattal járó kiadásokat. Ez az üzletmenet ritka, de jól mutatja a bizalom szerepét a gazdaságban.

Az előbb elmondottak fordítva is igazak: ha az üzletfelek között alacsony bizalmi szint tapasztalható, akkor emelkednek a tranzakciós és adminisztrációs költségek, ami hatékonyságvesztést eredményez (Capello, Caragliu, Nijkamp 2009,10 .). Ebben az esetben formális szervezeteket kell bevonni, melyek megállapítják, ellenőrzik, szükség esetén kikényszerítik a bonyolult szerződések normáit és passzusaiban foglaltakat. A bizalmatlanság miatt erősebb jogrendszerre van szükség, ami a gazdasági szereplők szempontjából forráskivonást jelent, az 
esetleges peres ügyek lelassítják a gazdasági folyamatokat és az innovációt, romlik a termelés hatékonysága.

A bizalmi viszony meghatározó tényezői a mikro- és a mezoszinten különbözőek. Mikroszinten négy tényező meghatározó: a személyes megjelenéssel járó benyomások, a másik fél reputációja, az előzetes sztereotípiák és a másik ellenőrizhetősége. A vállalatok közötti bizalmi viszony kialakulásáért és újratermelödéséért felelős tényezők: a cégek közötti kapcsolat kialakulásának története, a partnercég tulajdonságai, a menedzsment és az alkalmazottak viszonya, valamint a munkavállalók habitusa és attitüdje. Emellett fontos még a „vállalat struktúrája, irányítási formája és a személyzet összetétele." (Hodosi 2011, 77.)

Ki kell emelni, hogy a bizalom nem rövid, hanem hosszú távon térül meg, stratégiai befektetésként is felfogható, hozadékát csak ilyen időtávon lehet realizálni. Sőt, a kapcsolat elején, a bizalmi viszony megalapozásánál inkább többletköltségek jelentkeznek, nem pedig profit. Megteremtése, ápolása, fenntartása pénzt és időt követel, ennek finanszírozása egy későbbi időpontban fog csak előnnyel járni (Tátrai 2003).

A bizalom gazdasági szerepe a kereslet és kínálat aspektusából is elemezhető, a Schelling (1963) által tiszta közös érdeknek (pure common-interest) nevezett összefüggésrendszer figyelhető meg. A „tiszta közös érdek foglalja magában a bizalomra épülő, teljes együttmüködési szituációt, melyet a teljesen azonos célok összessége jellemez, s mely során mindenkinek ugyanaz a kifizetése." (Hodosi 2011, 77).

\section{E. Kapcsolati tőke}

A kapcsolati tőke a gazdasági szereplők kooperációjában nyilvánul meg, amelyet a köztük lévő információcsere hatékonysága határoz meg. A kapcsolati tőke - az előző tőkejószággal összefüggésben - három vonatkozásban is megjelenik: egyrészt a gazdasági döntések során csökkenti a bizalmatlanságot, másrészt javítja a munkaerö-piaci feltételeket a kollektív tanulás, a lexikális és nem lexikális ismeretek és tapasztalatok felhalmozásával, harmadrészt a regionális együttműködéssel minőségi javulás érhető el a gazdasági szereplők közötti interakcióban - ez utóbbi az informális kapcsolatok erősödése révén közös érdekképviseletet, klaszteresedési lehetőséget is jelent a globalizáció viszonyrendszerében (Capello, Fratesi 2010; Affuso, Capello, Fratesi 2011). A regionális érdekközösség, az általános erkölcs és a közös nyelv alapján olyan helyi miliő formálódik, amely stratégiai gazdasági előnyöket is garantálhat. Ilyen térszerkezetben az információáramlás is gyorsabb, ami koordinációs mechanizmusokon keresztül kedvezően hat a régió piaci folyamataira. Többnyire ez szervezi a helyi gazdasági egységek kollektív cselekvéseit, szelektálja a felesleges információkat a gazdasági döntések során, a kollektív tanulással pedig a piaci igényeknek megfelelő ismeretek és kompetenciák sajátíthatók el. 


\section{F. Humán tőke}

Az endogén növekedéselmélet szerint a regionális gazdasági folyamatokban a humán tőkejavak elsődleges szerephez jutnak, mert a térség helyi erőforrásait és attraktivitását egyszerre fejlesztik. Ide tartozik az együttműködésre való hajlandóság, a vállalkozói szellem, a kreativitás és a piaci szereplők közötti konzultáció.

A humán tőke szerves része a kulturális tőke, melynek jelentését a regionális tudományban Bourdieu (2004) munkásságához kötik. A kulturális tőke azért válik egyre fontosabbá, mert a tudás és a szélesebb értelemben vett kultúra - mint láthatatlan tőkeelem - gazdasági tőkévé alakítható át. A kulturális tőke három fajtája különböztethető meg: az inkorporált formában, a tárgyiasult formában és az intézményesített formában lévő kulturális tőkeelemek.

Az inkorporált javak közé a formális és informális szocializációs mechanizmusokon keresztül elsajátított vagy otthonról hozott érzelmeket, magatartásformákat, viselkedésmódokat, mentalitást, habitust soroljuk. Az újratermelési stratégiák során a nem lexikális (tacit) tudást és képességeket sajátítjuk el a társadalmi mezőben. Az inkorporált javak felhalmozása az egyén feladata, abba más személy nem vonható be. Az így megszerzett kompetenciák a szimbolikus tőke részeként az egyén tulajdonává válnak, segítségükkel a rendelkezésre álló források más tőkévé alakíthatók. Jellemző, hogy minél nagyobb mértékben halmozódnak fel az inkorporált kulturális javak, annál inkább átalakíthatók más tőkévé. Ennek mérésére általában a javak elsajátításához szükséges időt szokták használni, ami több évet vagy évtizedet is jelenthet.

A tárgyiasult kulturális tőke átalakítása könnyebb és gyorsabb, mint az előzőé. Felhalmozását megelőzi és meghatározza az inkorporált tőke létezése. Operacionalizálása egyszerü: általában könyvek, lexikonok, festmények, mütárgyak, értékes művészeti alkotások könnyen számszerüsíthető tulajdonlásában fejeződik ki. Nem szabad figyelmen kívül hagyni, hogy örökléskor vagy ajándékozáskor ezen tárgyak esetében kizárólag a tulajdonjog átadása történik meg, a tudás- és kompetenciaátadás azonban nem minden esetben valósul meg. A területi folyamatok alakulásában és a regionális növekedésben a kulturális tőkeelemnek kiemelkedő szerep jut, a kulturális tőke szignifikánsan meghatározza egy térség gazdasági kilátásait (Radvánszki, Sütő 2011). A térség társadalma a tradíciók, a sajátos történelem és a kapcsolatrendszerek révén a területi tőke organikus elemévé váló hallgatólagos tudást halmoz fel.

Az intézményesített kulturális tőkeelem tudományos címekben, szimbólumokban tárgyiasul. Ez az egyértelműen rétegképző, hierarchiát formáló ismérv a tudomány és az egyetem világában bizonyos kompetenciák elismertségét jelöli. Mérése megvalósulhat az adott térség felsőoktatási intézményeiben vagy kutatóhelyein tudományos fokozattal rendelkezők számával. Azokat a tudományos fokozatokat érdemes figyelembe venni egy ilyen mérésnél, amelyek az oktató részéről az adott régióban piacképes ismeretek átadását feltételezték (Polónyi, Tímár 2001). 


\section{G. Ügynökségek a K+F transzferére}

A regionális gazdasági egységek közötti társadalmi tőke gazdasági tőkévé alakítható át. Ebből a folyamatból a későbbiekben „bottom-up” típusú klaszterek is kialakulhatnak, melyek a regionális gazdasági fejlődés meghatározó elemeivé, motorjaivá válhatnak. A közelségből származó hatékonyabb összeköttetés, az urbanizációs és agglomerációs előnyök a helyi érdekérvényesítés javulását eredményezik, mindez az információcsere gyorsaságával és pontosságával válik mérhetővé. A globalizált világgazdaságban a régiók az állandó változásokhoz akkor tudnak alkalmazkodni, valamint a változásokat saját előnyükre alakítani, ha olyan fogadókészséget, mentalitást, attitűdöt alakítanak ki, amely őket az ilyen típusú nyitottságra alkalmassá teszi, abszorpciós (adott entitással összefüggő felszívó-) képességüket javítja.

\section{H. Kooperációs hálózatok}

Camagni fogalmi modelljében ez a szempont áll középen - nem véletlenül. A modell középpontjában álló tőkeelem integrálja a magán- és kollektív tulajdonban lévő, valamint a materiális és immateriális javakat. A gazdasági fejlődés tényezőit a térségekben a kooperációs hálózatok strukturálják, melyek többek között elosztási és újraelosztási szerepet töltenek be a tudás és a $\mathrm{K}+\mathrm{F}$ - piaci és kormányzati kudarcok (Stiglitz 2000) korrigálásában is egyre nagyobb szerepet vállaló - intézményrendszerével. Empirikus elemzések arra a következtetésre jutottak, hogy a kooperációs hálózatok jellemzően városokban, különleges társadalmi-gazdasági csoportokban vagy klaszterek által lefedett térségekben jönnek létre leggyorsabban, ahol megvalósul a lokális társadalom tagjai formális és hallgatólagos tudásának újraelosztása (Giffinger, Stallbohm 2009, 5.).

A kooperációs hálózatok elsődleges szerepe, hogy a tudásintenzív gazdasági egységek és a térség kulturális intézményrendszere közötti kongruenciát megteremtsék, valamint hogy kialakítsák az innovációs miliő köz- és magánszektor közötti terjedésének feltételrendszerét.

\section{Kapcsolati magánszolgáltatások}

A gazdasági egységek a piac automatizmusai révén kapcsolatot alakíthatnak ki egymással, ám tudatosan is kezdeményezhetnek nem piaci alapú viszonyokat (például egyetemekkel, kutatóhelyekkel), melyekből a térségben profitot realizálhatnak. Az ilyen együttműködés általában stratégiai fejlesztések sorába illeszthető, hosszú távú befektetést jelent, magas várható megtérüléssel.

\section{A területi tőke módszertani rendszere}

A területi tőke paradigmája összetett megközelítésen alapul, ezért kutatásmódszertana is komplex. Az elsőként Max Weber (1995) által kidolgozott sokdimen- 
ziós eljárást veszi alapul, a többváltozós elemzés módszertanait részesíti előnyben. A regionális folyamatok összetettségéhez szorosan illeszkedő módszertani rendszert alkalmaz, mely egyaránt lehet kvantitatív, kvalitatív (jellemzően félig strukturált interjúk) vagy ezek kombinációjára épülő eljárás. Napjainkban a kvantitatív módszerek dominálnak, eddig egy olyan kutatást ismerünk, amelyben a két módszertan szintézisét alkalmazták (Rota 2010). Kizárólag kvalitatív módszertannal még nem készült területitőke-felmérés. Valószínűleg a kvalitatív eljárások a jövőben erősödni fognak, mert az immateriális javak vizsgálata (például a területi miliő és identitás, a lokális bizalom) ezzel a módszerrel még pontosabban vizsgálható.

A kvantitatív módszerek közül jellemzően a MASST-modell (MAcroeconomic, Sectoral, Social and Territorial Model) segítségével vizsgálható a területi tőkeállomány, ${ }^{4}$ amelyet egy nemrég lezárt, területitőke-sajátosságokat elemző vizsgálat is sikerrel használt (Capello, Fratesi, Resmini 2011, 217-249.). A modell alkalmasságát még tudományos vita övezi, legitimációja felemásnak mondható (Capello 2007, 2008; Capello, Camagni 2008, 12-18.), rendszerint NUTS-2 régiók vizsgálatára alkalmazzák. Az ökonometriai modellel fel lehet térképezni egy térség területitőke-jellemzőit, meg lehet becsülni a regionális növekedés eltérő intenzitású tényezőinek változását, a szubszidiaritás elve alapján szcenáriókat lehet alkotni az eltérő növekedésű ütemü régiók kiegyensúlyozása érdekében, a múlt trendjeiből területi szcenáriók alkothatók. Eltérő tulajdonságú forgatókönyvek megalkotására - úgymint az alapvető területi jellemzők leírására vállalkozó, a versengő és a kohéziós területi forgatókönyvek (ESPON 2011) - ad lehetőséget. A trendeket általában 3-5 évre, vagy 15-20 évre képes előre jelezni.

A MASST-modell koncepcionális kiindulópontja, hogy egy régió növekedése kihat az egész ország teljesítményére, valamint a makrogazdasági fejlődés is meghatározza a regionális növekedést. Az egyes régiók növekedését összesítve megkapjuk a nemzetgazdaság növekedését - amely egy tipikus top-down jellegü felfogás.

A várható regionális fejlődést a MASST-modell (logikai felépítését lásd a 2. ábrán) két almodellel méri: a növekedés mértékét az ábra bal oldalán látható nemzetgazdasági összetevővel és a jobb oldalon szereplő regionálisan differenciált növekedésváltozással, majd egymással is összehasonlítja. A modellben tehát két egyenlet található: az egyik magyarázza a makrogazdasági fejlődést, a másik a regionálisan differenciált növekedést, vagyis a módszer komplex vertikális visszacsatolásra (feedback) alkalmas (Stimson, Stough, Nijkamp 2011, 221.). A regionális növekedést tehát a nemzetgazdasági növekedés és annak a regionális növekedéstől való eltérése összegeként fogja fel:

$$
\Delta \mathrm{YR}=\Delta \mathrm{YN}+\mathrm{S}
$$

ahol $\Delta \mathrm{YR}$ és $\Delta \mathrm{YN}$ a regionális és a nemzetgazdasági GDP változását, $\mathrm{S}$ pedig a kettő különbségét jelenti.

A modell alkalmazásával alapvetően két cél érhető el: egyrészt a régió helyzetét lehet differenciáltan bemutatni, másrészt területi szcenáriókat lehet kidolgozni 
2. ábra. A MASST modell logikai felépítése The logical structure of the MASST model

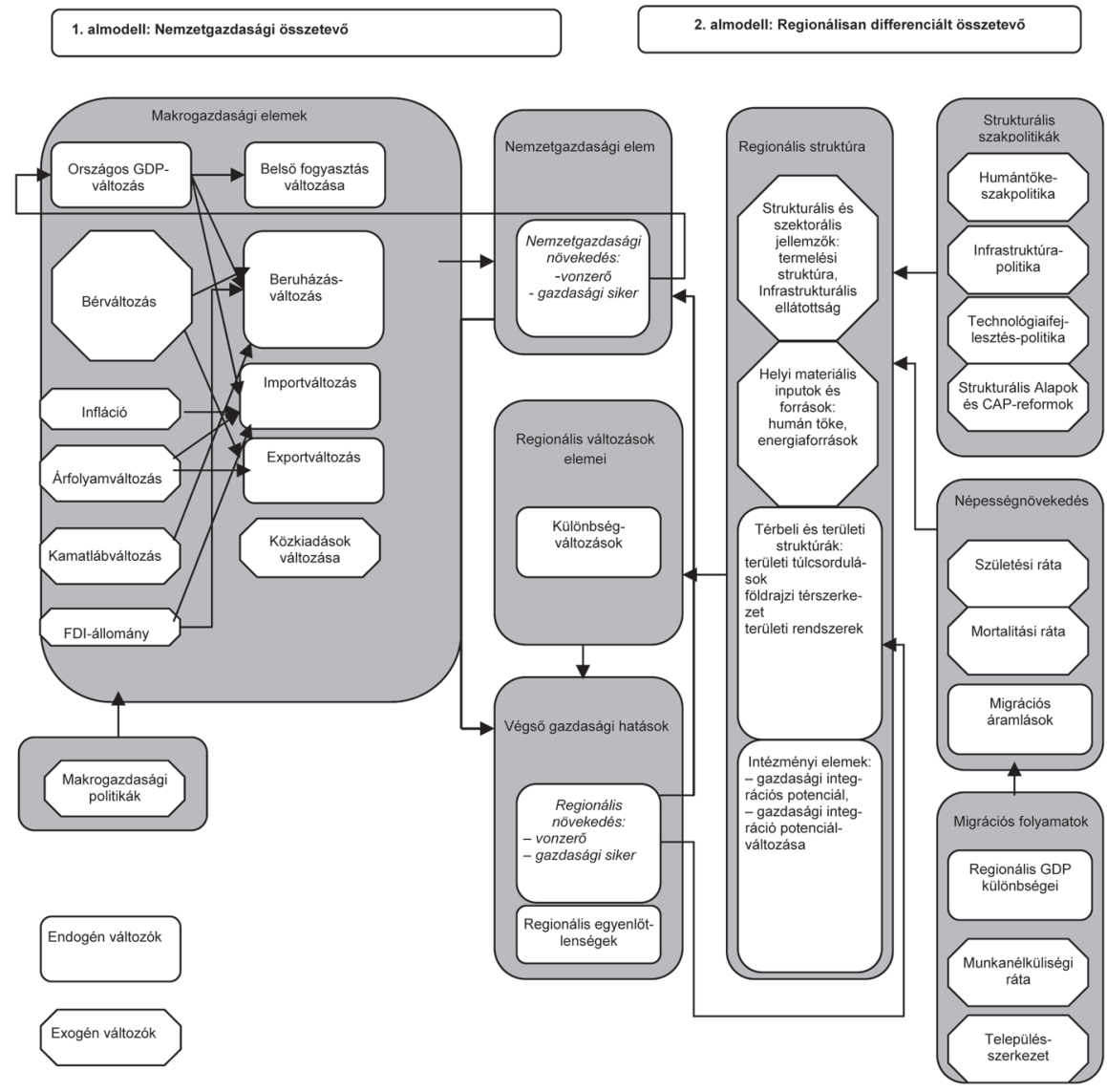

Forrás: Capello 2007, 760.

különböző időtávra - azaz a modell elemzői szerepe mellett előrebecslő lehetőséget is tartalmaz. A modell eredményei természetesen nem tökéletesen pontosak, ám irányokat, valószínűsített folyamatokat viszonylag jól jeleznek. A MASST-modell rendszerezi a területi tőke koncepciójának empirikus vizsgálatba bevont változóit, elkülöníti az endogén és exogén, a magyarázó és függo" változókat (Capello, Fratesi 2012). Ezzel segíti az ok-okozati viszonyok megértését és feltérképezését. Tehát alkalmas a jelenleg zajló, de dinamikusan változó lokális és interregionális folyamatok és viszonyok - nyilvánuljanak meg azok akár materiális, akár immateriális tőkeformákban - elemzésére, valamint jövőbeli szcenáriók megalkotására (Capello, Fratesi, Resmini 2011, 220-221.). Fontos megjegyeznem, hogy mivel a MASSTmódszert csak néhány éve dolgozták ki, ezért jelenleg folyamatos felülvizsgálata, korszerűsítése zajlik, empirikus tesztelése még korai fázisban van. 


\section{Összegzés}

A területi tőke koncepciójának bevezetésével és kidolgozásával a cél tehát az, hogy sajátos módszertani eljárásokkal operacionalizálhatóvá váljon egy adott régió materiális és immateriális tőkejavainak összessége, megállapítható legyen a területi tőke nagysága, azok minősége, a tőkefajták regionális megoszlása (Böhme 2011, 57.). Alkalmazása a helyi társadalom számára segít koncepciót alkotni a rendelkezésre álló tőkejavak kihasználásáról; az endogén fejlődés kapacitásainak bővítésével a gazdasági növekedés háttérfeltételeinek megerősitéséről. Ennek megvalósulásával hosszabb távon közelebb kerülhetünk a területi kohézióhoz és a közösségi integrációhoz, fejlődési pályára kerülhet a térgazdaság, nagyobb valószínűséggel teljesülhetnek a versenyképesség és a jólét megteremtésével összefüggésben álló szempontok (Ágh 2011, 42-43.; Faludi 2006, 669.). A területi tőke paradigmája olyan eszközrendszert kínál a területi tervezés, valamint a település- és területfejlesztés számára, mely támpontokat nyújthat az adott térségben található képességek megfelelő kihasználásához és újratermeléséhez.

\section{Jegyzetek}

1 A gazdasági növekedés, fejlődés és haladás jelentésbeli különbségeiről plasztikus elemzést nyújt Lengyel (2012) tanulmánya.

2 Kiemelkedő közgazdasági munka Schleifer és Glaeser (2003) műve, amely a bíróságok joggyakorlatának gazdasági hatását vizsgálja. De itt kell megemlíteni Kőszegit (2010) is, aki az emberi viselkedés és a gazdasági döntésmechanizmusok közötti viszonyt kutatja, vagy Kuran (2004) írását, aki az iszlám vallásgyakorlás és a gazdasági növekedés viszonyát elemzi.

3 Ebben a tanulmányban a vegyes javakat is a nem tárgyi tőkeelemekhez sorolom.

4 Ezen a ponton fontos egy megjegyzést tennem: napjainkban az ökonometriai elemzésekben egyre több helyen megjelenik a MASST-2 modell, amely az eredeti MASST-modell kiterjesztett, aktualizált formája. A regionális tudományban azonban nagyon ritkán használják a MASST-2 modell kifejezését, a MASST-modell alatt a MASST-2 modellt értik (Capello, Fratesi, Resmini 2011, 220.). A tanulmányban - a regionális tudomány gyakorlatát folytatva - én is MASST-2 értelemben használom a MASST-modell fogalmát.

\section{Irodalom}

Affuso, A., Camagni, R. (2010): Territorial capital and province performance in the Latin Arch: an econometric approach. http://www.grupposervizioambiente.it/aisre/pendrive2010/pendrive/paper/ affuso1.pdf (Letöltés: 2013. január 18.)

Affuso, A., Capello, R., Fratesi, U. (2011): Globalization and competitive strategies in European vulnerable regions. Regional Studies, 5., 657-675.

Ágh A. (2007): A régiók jövője Magyarországon és Magyarország jövője az Európai Unióban. In: Kaiser T., Ágh A., Kis-Varga J. (szerk.): A régiók Magyarországa. A regionális intézményrendszer körvonalai. MTA MEH Szociológiai Kutatóintézet, Budapest, 7-44. 
Ágh A. (2011): A közpolitika változó paradigmái: az érdekcsoportoktól a többszintű kormányzásig. Politikatudományi Szemle, 1., 31-48.

Barca, F. (2009): An agenda for a reformed cohesion policy. A placed-based approach to meeting European Union challenges and expectations.

http://www.europarl.europa.eu/meetdocs/2009_2014/documents/regi/dv/barca_report_/barca_ report_en.pdf (Letöltés: 2012. január 12.)

Bourdieu, P. (1983): The forms of capital. In: Richardson, J. G. (ed.): Handbook of theory and research for sociology of education. Greenwood, New York

Bourdieu, P. (2004): Gazdasági tőke, kulturális tőke, társadalmi tőke. In: Angelusz R. (szerk.): A társadalmi rétegződés komponensei. Új Mandátum Könyvkiadó, Budapest, 122-137.

Böhme, K. (2011): Visszaadni a lendületet - Gondolatok a magyar EU-elnökségről. Falu, Város, Régió, 1., 53-57.

Brenner, N. (2004): New state spaces. Urban governance and the rescaling of statehood. Oxford University Press, Oxford

Camagni, R. (2008): Regional competitiveness. Towards a concept of territorial capital. In: Capello, R., Camagni, R., Chizzolini, B., Fratesi, U. (eds.): Modelling regional scenarios for the enlarged Europe. Springer, Heidelberg, 33-46.

Camagni, R. (2009): Territorial capital and regional development. In: Capello, R., Nijkamp, P. (eds.): Handbook of regional growth and development theories. Edward Elgar, Cheltenham, Northampton, 118-132.

Camagni, R., Caragliu, A., Perucca, G. (2011): Territorial capital. Rational and human capital. http://www.grupposervizioambiente.it/aisre/pendrive2011/pendrive/paper/Camagni_Caragliu_ Perucca.pdf (Letöltés: 2013. január 18.)

Camagni, R., Fratesi, U. (2011): The territorial cohesion objective within European cohesion policies from a territorial capital perspective. DG-Regio and RSA Joint Conference "What Future for Cohesion Policy? An Academic and Policy Debate" Bled, március 16-18.

Capello, R. (2007): A forecasting territorial model of regional growth: the MASST model. The Annals of Regional Science, 4.,753-787.

Capello, R. (2008): The MASST model: a generative forecasting model of regional growth. In.: Capello, R., Camagni, R., Chizzolini, B., Fratesi, U. (eds.): Modelling regional scenarios for the enlarged Europe. Springer, Heidelberg, 85-98.

Capello, R., Camagni, R. (2008): Territorial capital and regional development in the EU. XXIX Conferenza Italiana di Scienze Regionali, Milano

Capello, R., Caragliu, A., Nijkamp, P. (2009): Territorial capital and regional growth: increasing returns in cognitive knowledge use. Tinburgen Institute Discussion Papers, 2009-059/3., Amsterdam

Capello, R., Fratesi, U. (2010): Globalization and a dual Europe: future alternative growth trajectories. The Annals of Regional Science, 3., 633-665.

Capello, R., Fratesi, U., Resmini, L. (2011): Globalization and regional growth in Europe. Past trends and future scenarios. Springer, Berlin

Capello, R., Fratesi, U. (2012): Modelling regional growth: an advanced MASST model. Spatial Economic Analysis, 3., 293-318.

Coleman, J. S. (1988): Social capital in the creation of human capital. American Journal of Sociology, S95-S120.

Czarnitzki, D., Hottenrott, H. (2009): Are local milieus the key to innovation performance? Journal of Regional Science, 1., 81-112.

Damsgaard, O. (2009): Territorial capital and spatial integration. Riga, április 21. www.vasab.org (Letöltés: 2012. január 14.)

Dansero, E., Mela, A. (2007). La territorialisation olympique: Le cas de jeux de Torino 2006. Revue de Géographie Alpine, 3., 5-26.

Dansero, E., Puttilli, M. (2010): Mega-events tourism legacies: the case of the Torino 2006 Winter Olympic Games - a territorialisation approach. Leisure Studies, 3., 321-341.

Dematteis, G., Governa, F. (2005). Il territorio nello sviluppo locale: Il contributo del modello SLOT. In: Dematteis, G. , Governa, F. (eds.), Territorialità, sviluppo locale, sostenibilità. Il modello SLOT. 
Franco Angeli, Milano, 15-38.

ESPON (2011): Helyünk és jövőnk Európában. http://www.espon.hu/Docs/ESPON_kiadvany_20111222.pdf (Letöltés: 2012. január 12.)

European Commission (2005): Territorial state and perspectives of the European Union. Scoping Document and Summary of Political Message. European Commission, Brussels

Fabbro, S., Mesolella, A. (2010): Multilevel spatial visions and territorial cohesion: Italian regional planning between the TEN-T corridors, ESDP polycentrism and Governmental 'Strategic Platforms'. Planning, Practice and Research, 1., 25-48.

Faludi, A. (2006): From European spatial development to territorial cohesion policy. Regional Studies, 6., 667-678.

Faludi, A. (2010): Territorial cohension post-2013: to whomsoever it may concern. 24th AESOP Annual Conference, Finland, július 7-10.

Giffinger, R. (2007): Territorial capital: a new perspective or urban competitiveness? SPA-CE.NET Conference Budapest, szeptember 26.

Giffinger, R., Gudrun, H. (2010): Smart cities ranking: an effective instrument for the positioning of cities? Architecture, City and Environment, 4., 7-25.

Giffinger, R., Haindlmaier, G., Kramar, H. (2010): The role of rankings in growing city competition. Urban Research and Practice, 3., 299-312.

Giffinger, R., Stallbohm, M. (2009): Challenges of metropolitan development: strategic efforts in comparison of Barcelona and Vienna. City Futures- EURA-UAA. "City Futures'09". Madrid, 1-21.

Giffinger, R., Suitner, J. (2010): Danube region strategy - arguments for a territorial capital based multilevel approach. Spatium International Review, October, 9-16.

Győrffy D. (2012): Intézményi bizalom és döntések időhorizontja. Közgazdasági Szemle, április, $412-426$.

Hodosi A. (2011): A bizalom mint költségcsökkentő tényező. Competitio, 2., 74-84.

Illés I. (2009): A területi kohézió szerepe az EU és a tagországok politikájában. In: Kocziszky Gy. (szerk.): Miskolci Egyetem Gazdaságtudományi Kar, VII. Nemzetközi Konferencia. Miskolci Egyetem, Miskolc, 214-224.

Jóna Gy., Tóth T. (2012): Concepts of the territorial capital. Selye E-studies, 3., 1-14. http://www.selyeuni.sk/ef/e-studies/

Köszegi, B. (2010): Utility from anticipation and personal equilibrium. Economic Theory, 44., 415-444.

Kunzmann, K. R. (2009): Mid-sized cities: territorial capital of Europe. Mid-size cities and the knowledge economy. IUFA Conference Bologna, június 13-17.

Kunzmann, K. R. (2011): After the global economic crisis: policy implications for the future of the European territory. Informationen zur Raumentwicklung, 8., 601-612.

Kuran, T. (2004): Why the Middle East is economically underdeveloped: historical mechanisms of institutional stagnation. Journal of Economic Perspectives, 3., 71-90.

Lengyel I. (2010): Regionális gazdaságfejlesztés. Versenyképesség, klaszterek és alulról szerveződo” stratégiák. Akadémiai Kiadó, Budapest

Lengyel I. (2012): Regionális növekedés, fejlődés, területi tőke és versenyképesség. In: Bajmócy Z., Lengyel I., Málovics Gy. (szerk.): Regionális innovációs képesség, versenyképesség és fenntarthatóság. JATEPress, Szeged, 151-174.

Luukkonen, J. (2010): Territorial cohesion policy in the light of peripherality. The Town Planning Review, 4., 445-466.

Marsden, T., Van der Ploeg, J. D. (2008) Some final reflections on rural social and spatial theory. In: Van der Ploeg, J. D., Marsden, T. (eds.) Unfolding webs - The dynamics of regional rural development. Van Gorcum, Assen, 225-233. OECD (2001): Territorial Outlook. Paris, OECD http://www.vwl.tuwien.ac.at/hanappi/AgeSo/SecReps/Territorial_Outlook_F.pdf(Letöltés: 2012. január 12.)

Polónyi I., Tímár J. (2001): Tudásgyár vagy papírgyár? Új Mandátum Kiadó, Budapest

Putnam, R. D. (2000): Bowling alone. Simon and Schuster, New York

Radvánszki Á., Sütő A. (2011): A Területi Agenda felülvizsgálatának megalapozása: az Európai Unió területi helyzetének és kilátásainak újragondolása. Falu, Város, Régió, 1., 17-34.

Rechnitzer J. (2010): Elit a területi folyamatokban - előszó egy kutatási programhoz. Tér és 
Társadalom, 2., 1-3.

Rota, F. S. (2010): The territorial embedment of global industrial networks. Theoretical insights and evidences from foreign MNCs' affiliates in Turin (Italy). Regional Studies Association Annual International Conference. http://www.regional-studies-assoc.ac.uk/events/2010/may-pecs/papers/Rota.pdf (Letöltés: 2012. augusztus 2.)

Russo, A. P., Servillo, L. (2011): Evidence-based cohesion policy: territorial dimensions. Krakow, november 29-30.

Russo, A. P., Smith, I., Atkinson, R., Servillo, L., Madsen, B., Borg, J., Otgaar, A. (2012): The attractiveness of regions and cities for residents and visitors. Interim Report. http://www.espon.eu/main/ Menu_Projects/Menu_AppliedResearch/attreg.html (Letöltés: 2012. október 1.)

Schelling, T. C. (1963): The strategy of conflict. Oxford University Press, New York

Schleifer, A., Glaeser, E. (2003): The rise of the regulatory state. Journal of Economic Literature, 2., 401-425.

Servillo, L. (2010): Territorial cohesion discourses: hegemonic strategic concepts in European spatial planning. Planning Theory and Practice, 3., 397-416.

Stein, A. (2010): Territorial cohesion in the context of interregional and transnational cooperation. European Spatial Research and Policy, 1., 5-22.

Stiglitz, J. E. (2000): A kormányzati szektor gazdaságtana. KJK-KERSZÖV, Budapest

Stimson, R., Stough, R. R., Nijkamp, P. (2011): Endogenous regional development. In.: Stimson, R., Stough, R. R., Nijkamp, P. (eds.): Endogenous regional development: perspectives, measurement and empirical investigation. Elgar, Northampton, 1-20.

Tátrai M. (2003): A bizalom szerepe a gazdasági kapcsolatokban. In: Hunyadi Gy., Székely M. (szerk.): Gazdaságpszichológia. Osiris Kiadó, Budapest, 676-715.

Tóth B. I. (2010): Az immateriális és a területi tőke összefüggései. Tér és Társadalom, 1., 65-81.

Tóth B. I. (2011): Changing endogenous development: the territorial capital. Journal of Economic and Business Research, 2., 137-151.

Veneri, P. (2011): Territorial identity in Italian NUTS-3 regions. http://www.grupposervizioambiente.it /aisre/pendrive2011/pendrive/paper/paper_vert_AN_june_2011.pdf (letöltve: 2013. január 18.)

Ventura, F., Milone, P., van der Ploeg, J. D. (2010): Understanding rural development dynamics. In: Milone, P., Ventura, F. (eds.): Networking the rural. Van Gorcum, Assen, 1-29.

Weber, M. (1995): Protestáns etika és a kapitalizmus szelleme. Cserépfalvi Kiadó, Budapest

World Bank (2006): Where is the wealth of nations? Measuring capital for the 21tst century. http://siteresources.worldbank.org/INTEEI/214578-1110886258964/20748034/All.pdf (Letöltés: 2012. január 12.)

Zamora, J., Jou, T., Williams, O. (2008): Territorial capital in Corpus Christi. http://josephzamora.netau.net/web_documents/!\%20My\%20Version\%20-20Territorial\%20 Capital\%20in\%20Corpus\%20Christi,\%20TX.pdf (Letöltés: 2012. január 12.)

Zonneveld, W., Waterhout, B. (2005): Visions on territorial cohesion. The Town Planning Review, 1., 15-27.

Zonneveld, W., Waterhout, B. (2010): Implications of territorial cohesion: an essay. Paper prepared for the Regional Studies Association Annual International Conference, Pécs, május 24-26. 